\title{
Effect of Enriched Gluten Free Biscuits with Chickpea Flour or Kareish Cheese on Chemical, Nutritional Value, Physical and Sensory Properties
}

\author{
Eman Abd El-Hamid Ahmad Abd Rabou \\ Home Economics Dept., Fac. of Specific Education, Aswan Univ.
}

\begin{abstract}
The purpose of this research was to investigat the effect of substitutions chickpea flour or kareish cheese with rice flour at different levels $(0,2.5,5,7.5,10$ and $12.5 \%)$ on chemical composition, nutritional evaluation, physical and sensory properties of gluten free sweet or salty biscuits. The results showed that as a result of increasing the levels of substitutions of chickpea flour or kareish cheese, the moisture, protein, ash and fat were increased. However carbohydrates contents were decreased compared to the other control samples on both types of biscuits. So, the nutritional value of both biscuits were increased compared to the control samples. Moreover, physical properties as the diameter of both biscuits were gradually decreased, but the thickness were increased. Thus, spread ratio was decreased by increasing chickpea flour or kareish cheese. Sweet biscuits with 10\% chickpea flour had the best sensory properties compared other sweet biscuits samples. Also, all salty biscuits had high sensory properties, but salty biscuits with $25 \%$ kareish cheese had the lowest properties compared to others. So, It can be formed gluten free biscuits with high nutritional value and good quality properties by adding chickpea flour by small quantity or kareish cheese by medium quantity.
\end{abstract}

Keywords: chickpea flour- kareish cheese- rice flour- sweet - salty -biscuits.

\section{INTRODUCTION}

Biscuit is one of the most commonly accepted snack foods amongst children and adult. It is considered as one of the best supplementary food for distributing to the undernourished children through developmental agencies (Mishra et al., 2015). The aglutenics biscuits are intended for those people who are suffering from gluten intolerance, (named celiac disease) (MAN et al., 2014). Celiac Disease is a chronic entheropathy produced by gluten intolerance, more precisely to certain proteins called prolamines, which causes atrophy of the intestinal villi, malabsorption and clinical symptoms that can appear in both childhood and adulthood (Osella et al., 2014 and Miñarro et al., 2012). Gluten is found in wheat, rye, barley, and other closely related cereal grains (Tsatsaragkou et al., 2012 and Deora et al., 2015).

In fact, many gluten-free products are available on the market are often of poor technological quality, exhibiting low volume, poor color and crumbling crumb, besides great variation in the nutrient composition, with low protein and high fat contents (Matos and Rosell, 2012). Thus, consumer demand is increasing for composite flour based bakery products like biscuits. Gluten-free nature can play an important role in preventing celiac problem (Baljeet et al., 2010). Glutinous rice flour is mainly used as a raw material in rice cakes and extruded snacks (Surojanametakul et al., 2006). Protein fortification of bakery products is of current interest because of increasing awareness in the consumer towards health and quality of bakery products (Figuerola et al., 2005) as biscuits can be prepared from composite flours (Mishra and Chandra, 2012) especially when cereals are blended with legumes (Oyarekua and Adeyeye, 2009) and dairy proteins (Matos et al., 2014).

Legumes flour is an ideal ingredient for improving the nutritional value of bread and bakery products (Hefnawy et al., 2012 and Koubaier et al., 2015). Chickpea (Cicer arietinum L) has a high protein, mostly contains high levels of complex carbohydrates (low glycemic index), is rich in vitamins and minerals and is relatively free from anti-nutritional factors (Wood and Grusak, 2007). Chickpea proteins are considered a suitable source of dietary protein due to the excellent balance of essential amino acid composition (Zhang et al., 2007).

Cheese has been widely used as an ingredient in various food, formulated food and prepared meals since the first recorded consumption of cheese itself. Cheese is an extremely versatile food product that has a wide range of textures, flavor and end uses. So, it is mainly to add flavor to food, texture, and nutritional quality (Lucey, 2008 and EL-Mahdi et al., 2014). Kareish cheese is one of the most popular, cheaper rich in nutrients and the oldest cheese in Egypt. It is a soft acid cheese made from naturally fermented skimmed milk and low fat. It comprises about $50 \%$ of white soft cheese (Romeoih et al., 2002, Hegazy et al., 2012 and El-Khawas and Hassaan, 2015). 
For these reasons this investigation was done to produce baked products like gluten free biscuits (sweet biscuits) by substituting chickpea flour with rice flour at $0,2.5,5,7.5,10$ and $12.5 \%$. In addition, to produce acceptable, oriental and healthy salty biscuits by substituting chickpea flour with rice flour at 5\% and kareish cheese at $0,2.5,5,7.5,10$ and $12.5 \%$. Then studying the effect of substitution on quality attributes of both samples of biscuits as chemical composition, nutritional value, physical and sensory properties.

\section{Materials:}

\section{MATERIALS AND METHODS}

Rice, peeled roasted chickpea, kareish cheese without salt, sugar, mixed spices (fennel and cumin at 1:1), salt, egg, butter, sunflower oil, full fat milk powder, vanilla, baking powder and were obtained from the local supermarket.

\section{Methods:}

Preparation of composite flour:

Peeled roasted chickpea or rice was milled by house mincer.

Preparation of sweet biscuits and salty biscuits:

Sweet and salty biscuits were prepared according to the formula shown in Table (1). Biscuits were prepared according to the procedure described by AACC (2000). Butter, oil and sugar or butter, oil and kareish cheese were creamed. Other dry ingredients were added to the cream. Then the dough was shaped as circles an outer diameter of 60 $\mathrm{mm}$ with $3 \mathrm{~mm}$ thickness. Then, the tow types of biscuits were baked at 180 to $190 \mathrm{C}$ for $20 \mathrm{~min}$. Finally, after cooling at room temperature biscuits samples were packed in low density polyethylene bags for further analysis of chemical, physical, and sensory proparties.

\section{Chemical analysis:}

Moisture, protein, ash and fat of biscuit samples were determined according to the method described by A.O.A.C. (2005). Total carbohydrate was calculated by differences.

\section{Physical properties of biscuits:}

Sweet and salty biscuits were analyzed for width, thickness and spread ratio was calculated by dividing the average value of diameter by average value of thickness of biscuits as described by A.O.A.C. (2005). The baking loss of biscuits was calculated by weighing five biscuits before and after baking. The difference in weight was averaged and reported as a percentage of baking loss as described by Chauhan et al., (2016).

\section{Sensory properties of biscuits:}

Sensory properties of all sweet or/ and salty biscuits as color, texture, flavor, crispiness and general acceptability were determined as the method described by Ihekoronye and Ngoddy (1985).

\section{Nutritional value of biscuits:}

The energy value of biscuit samples was calculated as described by A.O.A.C (2005). Grams consumed to cover the daily requirement (GDR) both energy and protein. Percent of satisfaction of protein and energy when consumed $100 \mathrm{~g}$ from biscuits samples (ps/100) from gram consumed to cover the daily requirements of energy value and protein for children (3-6 years) were calculated by using recommended daily allowance (RDA) as described by Anon, 1989.

Table 1: The formula of sweet and salty biscuits samples:

\begin{tabular}{|c|c|c|c|c|c|c|c|c|c|c|c|c|}
\hline \multirow{2}{*}{ Ingredient } & \multicolumn{6}{|c|}{ Sweet biscuits } & \multicolumn{6}{|c|}{ Salty biscuits } \\
\hline & RBC & RB1 & RB2 & RB3 & RB4 & RB5 & SRBC & SRB1 & SRB2 & SRB3 & SRB4 & SRB5 \\
\hline Rice flour & 50 & 47.5 & 45 & 42.5 & 40 & 37.5 & 52.14 & 49.64 & 47.14 & 44.64 & 42.14 & 39.64 \\
\hline Chickpea flour & & 2.5 & 5 & 7.5 & 10 & 12.5 & 5 & 5 & 5 & 5 & 5 & 5 \\
\hline Cottage Cheese & -- & -- & -- & -- & -- & -- & 0 & 2.5 & 5 & 7.5 & 10 & 12.5 \\
\hline Sugar & 15 & 15 & 15 & 15 & 15 & 15 & 1.13 & 1.13 & 1.13 & 1.13 & 1.13 & 1.13 \\
\hline Butter & 7.5 & 7.5 & 7.5 & 7.5 & 7.5 & 7.5 & 8.57 & 8.57 & 8.57 & 8.57 & 8.57 & 8.57 \\
\hline Sunflower oil & 2.5 & 2.5 & 2.5 & 2.5 & 2.5 & 2.5 & 2.86 & 2.86 & 2.86 & 2.86 & 2.86 & 2.86 \\
\hline $\begin{array}{l}\text { Full fat milk } \\
\text { powder }\end{array}$ & 2.5 & 2.5 & 2.5 & 2.5 & 2.5 & 2.5 & 2.86 & 2.86 & 2.86 & 2.86 & 2.86 & 2.86 \\
\hline Hen egg (whole) & 12.5 & 12.5 & 12.5 & 12.5 & 12.5 & 12.5 & 14.29 & 14.29 & 14.29 & 14.29 & 14.29 & 14.29 \\
\hline Baking powder & 2 & 2 & 2 & 2 & 2 & 2 & 2.29 & 2.29 & 2.29 & 2.29 & 2.29 & 2.29 \\
\hline Vanilla & 0.12 & 0.12 & 0.12 & 0.12 & 0.12 & 0.12 & 0.14 & 0.14 & 0.14 & 0.14 & 0.14 & 0.14 \\
\hline $\begin{array}{l}\text { Mixed spics } \\
\text { (feennel and } \\
\text { cumin at } 1: 1 \text { ) }\end{array}$ & -- & -- & -- & -- & -- & -- & 1.29 & 1.29 & 1.29 & 1.29 & 1.29 & 1.29 \\
\hline Salt & 0.38 & 0.38 & 0.38 & 0.38 & 0.38 & 0.38 & 0.86 & 0.86 & 0.86 & 0.86 & 0.86 & 0.86 \\
\hline Water & 7.5 & 7.5 & 7.5 & 7.5 & 7.5 & 7.5 & 8.57 & 8.57 & 8.57 & 8.57 & 8.57 & 8.57 \\
\hline Total & 100 & 100 & 100 & 100 & 100 & 100 & 100 & 100 & 100 & 100 & 100 & 100 \\
\hline
\end{tabular}

RBC: Rice biscuit control. RB1: Rice biscuits with 5\% chickpea flour. RB2: Rice biscuits with 10\% chickpea flour. RB3: Rice biscuits with 15\% chickpea flour. RB4: Rice biscuits with $20 \%$ Chickpea flour. RB5: Rice biscuits with $25 \%$ chickpea flour. SRBC: salty rice biscuits control- SRB1: Rice biscuits with $10 \%$ chickpea flour and 5\% kareish cheese. SRB3: Rice biscuits with 10\% chickpea flour and 10\% Kareish cheese. SRB4: Rice biscuits with 10\% chickpea flour and 15\% kareish cheese. SRB5: Rice biscuits with 10\% chickpea flour and 20\% kareish cheese. 


\section{Statistical analysis}

All Data were analyzed using the software, statistical package for social science (SPSS) version 11.00 SPSS inc., Chicago, IL, USA at the 0.05 level. The results were expressed as means \pm stander deviation (SD). Data were analyzed by using oneway analysis of variance (ANOVA) for continuous variables. $P$ values $<0.05$ were considered to be statistically significant.

\section{RESULTS AND DISCUSSION}

Chemical composition of raw materials used in preparation:

Data presented in Table (2) showed that rice flour had the highest content of carbohydrate and the lowest contents of protein, fat and ash compared to the other raw samples. On the other hand, kareish cheese had the highest contents of moisture, protein, ash and fat and the lowest content of carbohydrate. The result of the chemical composition of chickpea flours was confirmed by those of El-Shimy (2013) and Osorio-Díaz et al.,(2008) and Wani and Kumar (2014). The chemical composition of kareish cheese is in agreement with those of Ghada et al., (2004), and Awad et al., (2015) and El-Sayed et al.,
(2016). The result of rice flour chemical compostion was in agreement with those of Turabi et al., (2008).

Chemical composition of sweet and salty biscuit (dry weight basis).

Data found in Table (3) showed that there were slightly increased in moisture, protein, fat and ash contents, but there was slightly decreased in carbohydrate contents in both sweet and salty biscuits as increasing chickpea flour in sweet biscuits or increasing in karisk cheese levels in salty biscuits. The increasing in moisture content were due to increasing in levels of chickpea flour or kareish cheese as a result of increasing protein content in both kinds of biscuits. These results due to the fact that protein has high capability to absorb more water in products which cause increasing in moisture.

All these results agree with those of Rababah et al., (2006) and Saleh et al., (2012) they stated that the increase in moisture in biscuits could be due to the presence of polar amino acids and the positive influence of increasing levels of protein on waterholding capacity.

Table 2: Chemical composition of raw materials used in biscuits preparation on dry wieght

\begin{tabular}{lrrrrrr}
\hline Constituents & Moisture (\%) & Dry matter & Protein (\%) & Fat (\%) & Ash (\%) & Carbohydrate (\%) \\
\hline Rice flour & $\mathrm{b} 8.59 \pm 0.01$ & $\mathrm{~b} 91.41 \pm 0.11$ & $\mathrm{c} 6.21 \pm 0.16$ & $\mathrm{c} 1.22 \pm 0.26$ & $\mathrm{c} 0.35 \pm 0.23$ & $\mathrm{a} 92.24 \pm 0.1$ \\
Chickpea flour & $\mathrm{c} 7.58 \pm 0.12$ & $\mathrm{a} 92.42 \pm 0.12$ & $\mathrm{~b} 24.56 \pm 0.53$ & $\mathrm{~b} 7.52 \pm 0.53$ & $\mathrm{~b} 3.74 \pm 0.16$ & $\mathrm{~b} 64.18 \pm 0.08$ \\
Kareish cheese & $\mathrm{a} 81.75 \pm 0.65$ & $\mathrm{c} 18.25 \pm 0.65$ & $\mathrm{a} 65.75 \pm 0.05$ & $\mathrm{a} 8.38 \pm 0.35$ & $\mathrm{a} 11.23 \pm 0.058$ & $\mathrm{c} 14.64 \pm 0.14$ \\
P< & $* * *$ & $* * *$ & $* * *$ & $* * *$ & $* * *$ & $* * *$ \\
\hline
\end{tabular}

Each record is a mean value of three replicates and is followed by the stander deviation (SD). (a, b, c, d, e, and f): means in the same column with different superscript differ significantly at $\mathrm{p}<0.05$. ${ }^{*} \mathrm{P}<0.05$. $* * \mathrm{P}<0.01$. $* * * \mathrm{P}<0.001$.

Table 3: Chemical composition of sweet and salty biscuits on dry weight

\begin{tabular}{|c|c|c|c|c|c|c|}
\hline \multirow{2}{*}{ Samples } & \multicolumn{6}{|c|}{ Sweet biscuits } \\
\hline & Moisture & Dry matter & Protein & Fat & Ash & Carbohydrates \\
\hline $\mathrm{RBC}$ & $\mathrm{d} 5.14 \pm 0.15$ & a94.86 \pm 015 & f $7.93 \pm 0.17$ & d $19.42 \pm 0.07$ & F $0.94 \pm 0.12$ & a71.71 \pm 0.22 \\
\hline RB1 & $\operatorname{cd} 5.34 \pm 0.08$ & ab $94.66 \pm 0.08$ & e $8.54 \pm 0.06$ & d $19.49 \pm 0.08$ & $\mathrm{e} 1.06 \pm 0.05$ & b70.91 \pm 0.18 \\
\hline RB2 & c5.56 \pm 0.20 & b $94.44 \pm 0.2$ & d $8.99 \pm 0.14$ & $\mathrm{~d} 19.58 \pm 0.07$ & $\mathrm{~d} 1.20 \pm 0.05$ & c70.23 \pm 0.22 \\
\hline RB3 & b5.89 \pm 0.08 & c $94.11 \pm 0.08$ & c $9.74 \pm 0.12$ & c $19.77 \pm 0.06$ & $\mathrm{c} 1.32 \pm 0.03$ & $\mathrm{~d} 69.17 \pm 0.17$ \\
\hline RB4 & b6.12 \pm 0.05 & c $93.88 \pm 0.05$ & b $10.36 \pm 0.04$ & b $19.96 \pm 0.11$ & $\mathrm{~b} 1.47 \pm 0.02$ & $\mathrm{e} 68.21 \pm 0.09$ \\
\hline RB5 & $\mathrm{a} 6.50 \pm 0.12$ & $\mathrm{~d} 93.50 \pm 0.12$ & a $10.74 \pm 0.14$ & a $20.2 \pm 0.09$ & a $1.59 \pm 0.06$ & $\mathrm{f} 67.47 \pm 0.15$ \\
\hline $\mathrm{P}<$ & $* * *$ & $* * *$ & $* * *$ & $* * *$ & $* * *$ & $* * *$ \\
\hline \multicolumn{7}{|c|}{ Salty biscuits } \\
\hline SRBC & $\mathrm{e} 5.25 \pm 0.05$ & a94.75 \pm 0.05 & $\mathrm{f} 8.87 \pm 0.06$ & $\mathrm{f} 19.53 \pm 0.07$ & f1. $57 \pm 0.08$ & a70.03 \pm 0.08 \\
\hline SRB1 & $\mathrm{d} 5.70 \pm 0.05$ & b94.3 \pm 0.05 & $\mathrm{e} 10.03 \pm 0.15$ & $\mathrm{e} 21.04 \pm 0.06$ & $\mathrm{e} 1.89 \pm 0.05$ & $\mathrm{~b} 67.04 \pm 0.05$ \\
\hline SRB2 & c6.75 50.16 & bc93.25 \pm 0.16 & $\mathrm{~d} 10.71 \pm 0.04$ & $\mathrm{~d} 21.94 \pm 0.11$ & $\mathrm{~d} 2.03 \pm 0.14$ & c65.32 \pm 0.14 \\
\hline SRB3 & $\mathrm{b} 8.04 \pm 0.08$ & $\mathrm{~d} 91.96 \pm 0.08$ & $\mathrm{c} 11.48 \pm 0.06$ & $\mathrm{c} 22.97 \pm 0.05$ & $\mathrm{c} 2.17 \pm 0.02$ & $\mathrm{~d} 63.38 \pm 0.07$ \\
\hline SRB4 & a9.19 \pm 0.09 & e90.81 \pm 0.09 & $\mathrm{~b} 12.27 \pm 0.26$ & $\mathrm{~b} 24 \pm 0.89$ & $\mathrm{~b} 2.36 \pm 0.03$ & $\mathrm{e} 61.37 \pm 0.01$ \\
\hline SRB5 & a9.30土.04 & e90.70 \pm 0.04 & a12.5 \pm 0.55 & a25.52 \pm 035 & a2.64 \pm 0.53 & f59.34 \pm 0.76 \\
\hline $\mathrm{P}<$ & $* * *$ & $* * *$ & $* * *$ & $* * *$ & $* * *$ & $* * *$ \\
\hline
\end{tabular}

RBC: Rice biscuit control. RB1: Rice biscuits with 5\% chickpea flour. RB2: Rice biscuits with 10\% chickpea flour. RB3: Rice biscuits with 15\% chickpea flour. RB4: Rice biscuits with 20\% Chickpea flour. RB5: Rice biscuits with $25 \%$ chickpea flour. SRBC: salty rice biscuits control- SRB1: Rice biscuits with $10 \%$ chickpea flour and 5\% kareish cheese. SRB3: Rice biscuits with 10\% chickpea flour and 10\% Kareish cheese. SRB4: Rice biscuits with 10\% chickpea flour and $15 \%$ kareish cheese. SRB5: Rice biscuits with 10\% chickpea flour and 20\% kareish cheese.

Each record is a mean value of three replicates and is followed by the stander deviation (SD). (a, b, c, d, e, and f): means in the same column with different superscript differ significantly at $\mathrm{p}<0.05$. ${ }^{*} \mathrm{P}<0.05$. ${ }^{*} * \mathrm{P}<0.01$. $* * * \mathrm{P}<0.001$. 
It is taking into consideration the high moisture content associated with using the chickpea flour at different replacement levels, due to higher hydration rate that is associated with higher protein content. Furthermore, the result of salty biscuits is in agreement with those of An et al., (2005) they found that that dairy protein characterized by the great water binding capacity and the ability to form a gellike structures.

All the results about the effect of substituting chickpea flour with rice on sweet biscuits chemical compostion conformed with those of Mishra and Chandra (2012) Saleh et al., (2012), Yamsaengsung et al., (2012), El-Shimy (2013), Izembaeva et al., (2013) and Patil et al., (2016) they found that the incorporation of high protein legumes as chickpea flour can improve the nutritional value of cereal or gluten-free biscuit in particular, which are up to now often of poor quality. All the results about the effect of substituting chickpea flour with rice flour and kareish cheese on salty biscuits chemical compostion are in agreement with those of Gularte et al., (2012) they found that the incorporation of dairy proteins in the bakery products increased the protein content and complement the nutritional value of cereal proteins.

Nutritional value of the tested samples biscuits:

Data given in Table (4) presented that one serving $(100 \mathrm{~g})$ of both sweet and salty biscuits and its percent of satisfaction percentage (PS/100g) for children 3-6 years were slightly increased in
(PS/100g) of protein, so the GDR protein value was slightly decreased as increasing chickpea flour levels in sweet biscuits or increasing in kareish cheese levels in salty biscuits. But, the energy values (Kcal $/ 100 \mathrm{~g}$ ) of both biscuits were decreased, so GDR energy values were increasing in both biscuits. These results were due to slightly increasing protein and the decreasing carbohydrate content in both biscuits as found in Table (3). But, the percentage of one serving $100 \mathrm{~g}$ (PS/100g) of salty biscuits samples was more than that of sweet biscuits, because salty biscuits had more protein, fat contents and energy value (Kcal $/ 100 \mathrm{~g}$ ) than those of sweet biscuits samples.

All the results about sweet biscuits are in agreement with those of Oyarekua and Adeyeye, (2009) they reported that composite flour has the added advantages of improving the nutrient value of biscuits and other bakery products, especially when cereals are blended with legumes. Also, the results about salty biscuits are confirmed by those of Ghada et al., (2004), Gularte et al., (2012) and EL-Mahdi et al., (2014).

\section{Physical properties of biscuits}

Data available in Table (5) displayed that the diameter of sweet biscuits were decreased, but the thickness was increased so, spread ratio was decreased as increasing chickpea flour levels in sweet biscuits or as increasing kareish cheese levels on salty biscuits samples.

Table 4: Energy value, GDR and PS/100g (protein and energy value) of biscuits samples in wet weight for children 3-6 years

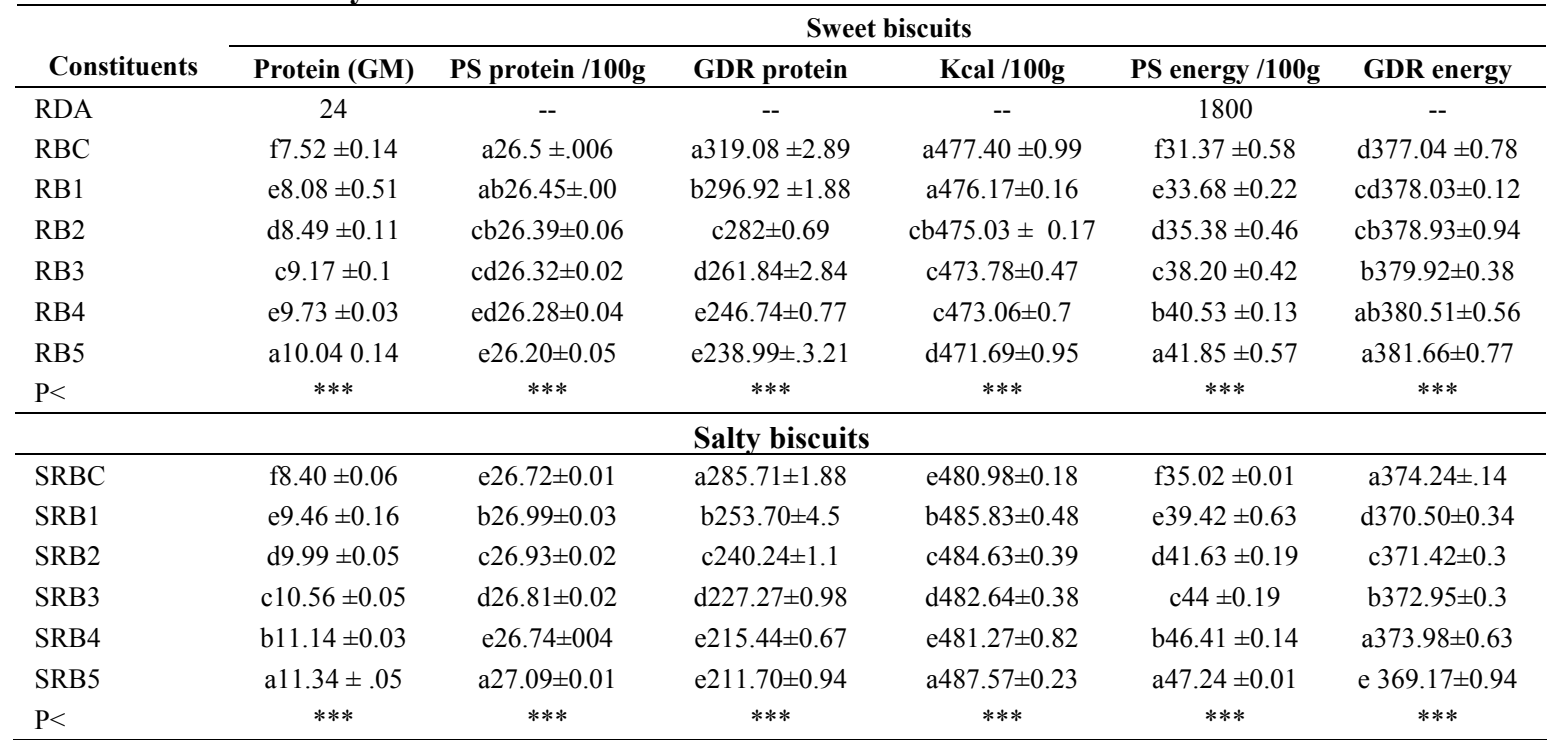

RBC: Rice biscuit control. RB1: Rice biscuits with 5\% chickpea flour. RB2: Rice biscuits with 10\% chickpea flour. RB3: Rice biscuits with 15\% chickpea flour. RB4: Rice biscuits with 20\% Chickpea flour. RB5: Rice biscuits with 25\% chickpea flour. SRBC: salty rice biscuits control- SRB1: Rice biscuits with $10 \%$ chickpea flour and $5 \%$ kareish cheese. SRB3: Rice biscuits with 10\% chickpea flour and 10\% Kareish cheese. SRB4: Rice biscuits with 10\% chickpea flour and $15 \%$ kareish cheese. SRB5: Rice biscuits with 10\% chickpea flour and $20 \%$ kareish cheese.

RDA: recommended daily allowance GDR: Grams consumed to cover the daily requirement. Ps: Percent of satisfaction

Each record is a mean value of three replicates and is followed by the stander deviation (SD) (a, b, c, d, e, and f): means in the same column with different superscript differ significantly at $\mathrm{p}<0.05$. ${ }^{*} \mathrm{P}<0.05 .{ }^{*} \mathrm{P}<0.01 .{ }^{* * *} \mathrm{P}<0.001$. ${ }^{* * * *} \mathrm{P}<0.0001$ 
Table 5: physical properties of the tested samples biscuits

\begin{tabular}{lcccc}
\hline & \multicolumn{4}{c}{ Sweet biscuits } \\
\cline { 2 - 5 } Samples & Diameter $(\mathbf{c m})$ & Thickness $(\mathbf{c m})$ & Spread ratio & \% Baking loss \\
\hline RBC & $\mathrm{a} 5.14 \pm 0.1$ & $\mathrm{c} 0.68 \pm 0.1$ & $\mathrm{a} 7.56 \pm 0.11$ & $\mathrm{a} 15.68 \pm 0.15$ \\
RB1 & $\mathrm{ab} 5.1 \pm 0.1$ & $\mathrm{c} 0.69 \pm 0.00$ & $\mathrm{ab} 7.39 \pm 0.15$ & $\mathrm{~b} 14.14 \pm 0.16$ \\
RB2 & $\mathrm{b} 5.05 \pm 0.05$ & $\mathrm{cb} 0.7 \pm 0.01$ & $\mathrm{~b} 7.21 \pm 0.95$ & $\mathrm{~b} 13.94 \pm 0.08$ \\
RB3 & $\mathrm{c} 4.98 \pm 0.1$ & $\mathrm{ab} 0.72 \pm 0.1$ & $\mathrm{c} 6.92 \pm 0.08$ & $\mathrm{c} 13.52 \pm 0.72$ \\
RB4 & $\mathrm{c} 4.96 \pm 0.04$ & $\mathrm{a} 0.73 \pm 0.1$ & $\mathrm{c} 6.79 \pm 0.16$ & $\mathrm{~d} 12.18 \pm 0.45$ \\
RB5 & $\mathrm{d} 4.78 \pm 0.17$ & $\mathrm{a} 0.74 \pm 0.1$ & $\mathrm{~d} 6.46 \pm 0.89$ & $\mathrm{c} 11.85 \pm 0.5$ \\
P< & $* * *$ & $* * *$ & $* * *$ & $* * *$ \\
\hline & & Salty biscuits & & $\mathrm{c} 46.57 \pm 0.40$ \\
SRBC & $4.89 \pm 0.23$ & $\mathrm{c} 0.75 \pm 0.1$ & $\mathrm{a} 6.52 \pm 0.61$ & $\mathrm{c} 46.91 \pm 0.12$ \\
SRB1 & $4.85 \pm 0.07$ & $\mathrm{~b} 0.82 \pm 0.04$ & $\mathrm{~b} 5.92 \pm 0.24$ & $\mathrm{c} 47.48 \pm 0.27$ \\
SRB2 & $4.8 \pm 0.05$ & $\mathrm{ab} 0.86 \pm 0.10$ & $\mathrm{bc} 5.58 \pm 0.13$ & $\mathrm{~b} 48.68 \pm 0.69$ \\
SRB3 & $4.8 \pm 0.1$ & $\mathrm{a} 0.89 \pm 0.01$ & $\mathrm{c} 5.35 \pm 0.12$ & $\mathrm{~b} 49.54 \pm 0.56$ \\
SRB4 & $4.8 \pm 0.1$ & $\mathrm{a} 0.9 \pm 0.02$ & $\mathrm{c} 5.33 \pm 0.06$ & $\mathrm{a} 50.98 \pm 0.17$ \\
SRB5 & $4.79 \pm 0.16$ & $\mathrm{a} 0.92 \pm 0.03$ & $\mathrm{c} 5.21 \pm 0.32$ & $* * *$ \\
P< & -- & $* * *$ & $* * *$ & \\
\hline
\end{tabular}

RBC: Rice biscuit control. RB1: Rice biscuits with 5\% chickpea flour. RB2: Rice biscuits with 10\% chickpea flour. RB3: Rice biscuits with 15\% chickpea flour. RB4: Rice biscuits with 20\% Chickpea flour. RB5: Rice biscuits with 25\% chickpea flour. SRBC: salty rice biscuits control- SRB1: Rice biscuits with 10\% chickpea flour and 5\% kareish cheese. SRB3: Rice biscuits with $10 \%$ chickpea flour and 10\% Kareish cheese. SRB4: Rice biscuits with 10\% chickpea flour and 15\% kareish cheese. SRB5: Rice biscuits with 10\% chickpea flour and 20\% kareish cheese.

Each record is a mean value of three replicates and is followed by the stander deviation (SD). (a, b, c, d, e, and f): means in the same column with different superscript differ significantly at $\mathrm{p}<0.05$. ${ }^{*} \mathrm{P}<0.05$. ${ }^{* *} \mathrm{P}<0.01 .{ }^{* * *} \mathrm{P}<0.001$.

On the other hand, \% baking loss of sweet biscuits was decreased as increasing levels of chickpea flour. This result was due to chickpea flour had low moisture and more protein persentage compared to rice as shown in Table (2). On the other hand, \% baking loss of salty biscuits was increased. This result was due to kariesh cheese has more moisture compared to rice flour in dough. These results were due to increase protein content which had the ability to bind water absorption and the hydrophilic nature of the flour chickpea in sweet biscuits. These result are in agreement with those of Thongram et al., (2016) and Mariotti et al., (2009). Besides, the result about salty biscuits is confirmed by those of Gallagher et al., (2005) and Hussein et al., 2008).

\section{Sensory evaluation of biscuits:}

Data presented in Table (6) showed that darker yellowness, darker color and aroma were increased by increasing the level of substitution of chickpea flour. These results may be due to increasing fiber and carotenoids. This result confirmed with those by Hu et al. (2007) and Fărcaş et al. (2014). Hardness and aroma were increased by increaseing chickpea flour levels. This result is in agreement with those of Yamsaengsung et al., (2012). All formulas of biscuits were acceptable, but the best form of sweet biscuit which had 10\% chickpea flour. This result confirmed with those of Ahmad and Ahmed, (2014) they reported that supplementary food should be such, if taken in small quantity, could provide the necessary amount of nutrients. They should be made in the form of ready to eat snacks, drinks. All these results are confirmed by those of Sulieman et al., (2013) Izembaeva et al., (2013) and Man et al., (2015).

The acceptability of salty biscuits was increased by increasing kareish cheese levels because all properties of salty biscuits were improved. These results due to the functionality of milk constituents. Proteins, fat, lactose and minerals have a profound positive influence on the quality of non-dairy food product, when dairy ingredients are used in such product mix (Krupa et al., 2011 and (EL-Mahdi et $a l ., 2014)$. Also, crust darkening is increased this result due to maillard reactions this result is in agreement with those of De Mesa-Stonestreet et al., 2012 and Krupa et al., 2011).

All these results are confirmed by those of Mariotti et al., (2009) they reported that incorporation of starches of different origin, dairy proteins, other non-gluten proteins into a gluten free flour base (mostly rice and corn flour) that could result in maintaining the structure, mouth feel, acceptability and shelf-life of the finished products. Also, Izembaeva et $a l$. , (2013) reported that proteins do not only play an important role in the body, but also in the technological process to prepare the dough, in the formation of flavoring and aromatic substances, baking cookies, determine many important consumer properties of food products. 
Table 6: Sensory evaluation of the tested samples biscuits.

\begin{tabular}{|c|c|c|c|c|c|c|c|}
\hline \multirow{2}{*}{ Samples } & \multicolumn{7}{|c|}{ Sweet biscuits } \\
\hline & Color & Taste & Aroma & Criccpess & Texture & Crust & Acceptability \\
\hline $\mathrm{RBC}$ & $\mathrm{a} 8.8 \pm 0.42$ & $\mathrm{ab7.9 \pm 0.32}$ & a9.1 \pm 0.57 & c7.6 \pm 0.52 & c6.8 40.42 & ba8.1 $1 \pm 0.32$ & $\operatorname{cb} 7.98 \pm 0.2$ \\
\hline RB1 & $\mathrm{a} 8.8 \pm 0.62$ & $\mathrm{ab} 7.9 \pm 0.74$ & $\mathrm{ab} 8.9 \pm 0.57$ & $\mathrm{ab} 8.2 \pm 0.79$ & ba7. $5 \pm 0.53$ & $\mathrm{a} 8.4 \pm 0.52$ & ba8 $8.22 \pm 0.37$ \\
\hline $\mathrm{RB} 2$ & $\mathrm{ab} 8.5 \pm 0.42$ & $\mathrm{a} 8.1 \pm 0.57$ & $\mathrm{ab} 8.75 \pm 0.72$ & $\mathrm{a} 8.5 \pm 0.53$ & ba7.5 \pm 0.57 & $\mathrm{a} 8.45 \pm 0.60$ & $\mathrm{a} 8.35 \pm 0.19$ \\
\hline RB3 & $\mathrm{ab8} .13 \pm 0.32$ & $\mathrm{cb} 7.25 \pm 0.64$ & $\operatorname{cb} 8.25 \pm 0.43$ & $\mathrm{a} 8.75 \pm 0.9$ & $a b c 7.4 \pm 0.52$ & b7.51 \pm 0.47 & c7.87 \pm 0.15 \\
\hline RB4 & $\mathrm{ab8} .13 \pm 0.49$ & c7.18 \pm 0.34 & $\mathrm{c} 7.75 \pm 0.64$ & $\mathrm{a} 8.95 \pm 0.5$ & cb7.13 \pm 0.5 & b7.65 \pm 0.47 & $\operatorname{cd} 7.78 \pm 0.22$ \\
\hline RB5 & $\mathrm{b} 8 \pm 0.67$ & c7.0 \pm 0.67 & $\mathrm{~d} 6.5 \pm 0.53$ & $\mathrm{a} 9 \pm 0.82$ & $\mathrm{cb} 7 \pm 0.47$ & b7.75 \pm 0.64 & d7.54 \pm 0.28 \\
\hline $\mathrm{F}$ & 3.662 & 6.706 & 27.911 & 5.485 & 6.124 & 6.124 & 14.438 \\
\hline $\mathrm{P}<$ & $* *$ & $* * *$ & $* * *$ & $* * *$ & $* * *$ & $* * *$ & $* * *$ \\
\hline \multicolumn{8}{|c|}{ Salty biscuits } \\
\hline SRBC & $8.0 \pm 0.47$ & c8.1 \pm 0.32 & c8. $2 \pm 0.42$ & $a b 8.5 \pm 0.53$ & $\mathrm{c} 8 \pm 0.67$ & $\mathrm{a} 8.4 \pm 0.52$ & c8.20 0.23 \\
\hline SRB1 & $8.4 \pm 0.52$ & c $8.3 \pm 0.48$ & $\operatorname{cb} 8.5 \pm 0.71$ & $\mathrm{ab} 8.2 \pm 0.63$ & $\operatorname{cb} 8.5 \pm 0.71$ & $\mathrm{ab} 8.2 \pm 0.79$ & $\mathrm{ab} 8.35 \pm 0.43$ \\
\hline SRB2 & $8.4 \pm 0.7$ & $\operatorname{cb} 8.6 \pm 0.52$ & bc $8.75 \pm 0.62$ & $a b 8.1 \pm 0.99$ & ba8.9 \pm 0.57 & $\mathrm{ab} 7.95 \pm 0.6$ & $\mathrm{ab} 8.45 \pm 0.24$ \\
\hline SRB3 & $8.4 \pm 0.7$ & ba9. $1 \pm 0.88$ & ba8.98 \pm 0.41 & $\mathrm{ab} 7.85 \pm 0.24$ & ba9. $2 \pm 0.42$ & $a b 7.71 \pm 0.48$ & $\mathrm{ab} 8.54 \pm 0.33$ \\
\hline SRB4 & $8.45 \pm 0.5$ & a9.3 \pm 0.48 & a9. $5 \pm 0.53$ & b7. $5 \pm 0.53$ & ba9.15 \pm 0.63 & c7. $55 \pm 0.5$ & $\mathrm{a} 8.58 \pm 0.58$ \\
\hline SRB5 & $8.6 \pm 0.7$ & a9.35 \pm 0.47 & a9. $6 \pm 0.52$ & b7. $45 \pm 0.5$ & a9.3 \pm 0.48 & c7.5 \pm 0.53 & a8.63 \pm 0.17 \\
\hline $\mathrm{F}$ & 1.083 & 9.351 & 10.198 & 4.524 & 7.318 & 3.969 & 3.407 \\
\hline $\mathrm{P}<$ & --- & $* * *$ & $* * *$ & $* * *$ & $* * *$ & $* *$ & ** \\
\hline
\end{tabular}

RBC: Rice biscuit control. RB1: Rice biscuits with 5\% chickpea flour. RB2: Rice biscuits with 10\% chickpea flour. RB3: Rice biscuits with 15\% chickpea flour. RB4: Rice biscuits with 20\% Chickpea flour. RB5: Rice biscuits with $25 \%$ chickpea flour.SRBC: salty rice biscuits control- SRB1: Rice biscuits with $10 \%$ chickpea flour and 5\% kareish cheese. SRB3: Rice biscuits with 10\% chickpea flour and 10\% Kareish cheese. SRB4: Rice biscuits with 10\% chickpea flour and 15\% kareish cheese. SRB5: Rice biscuits with 10\% chickpea flour and 20\% kareish cheese.

Each record is a mean value of ten replicates and is followed by the stander deviation (SD). (a, b, c, d, e, and f): means in the same column with different superscript differ significantly at $\mathrm{p}<0.05$. $* \mathrm{P}<0.05$. $* * \mathrm{P}<0.01 . * * * \mathrm{P}<0.001$.

\section{CONCLUSION}

Substitution gluten free as rice by chickpea flour or kareish cheese to produce baked products like sweet and salty biscuits. It can produce gluten free biscuits with high nutritional value, high physical and sensory propertie, by adding chickpea flour by small quantity or kareish cheese with medium quantity.

\section{REFERENCES}

A.O.A.C (2005). Official Methods of Analysis. Association of Official Analytical Chemists. 18th Ed. Washington, D.C

AACC. (2000). American Association of Cereal Chemists. Approved Method of the AACC. 10th Ed. American Association of Cereal Chemists, St., Paul, Minnesota, USA.

Ahmad, S., and Ahmed, M. (2014). A review on biscuit, a largest consumed processed product in India, its fortification and nutritional improvement. IJSIT, 3 (2), 169-186.

An, Y-H., Gang, D-O. and Shin, M-S. (2005). Effects of transglutaminase on the physical properties of resistant starch-added wheat flour doughs and baguettes. Food Sci. Biotechnology. 14, 608-613.

Anon. (1989). RDA Recommended Dietary Allowances, Food And Nutritive Board. National Academy of Sci. National Res. Council. Washington, D.C.
Awad,R.A., Salama, W. M. and Ragb, W. A. (2015). Enhancing yield and acceptability of Kareish cheese made of Reformulated milk. Annals of Agric Sci. 60(1), 87-93.

Baljeet, S.Y, Ritika, B.Y. and Roshan, L.Y. (2010). Studies on functional properties and incorporation of buckwheat flour for biscuit making. Int Food Res. J. 17: 1067-1076 .

Chauhan, A., Saxena, D.C. and Singh,S. (2016). Physical, textural, and sensory characteristics of wheat and amaranth flour blend cookies. Cogent Food \& Agric. 2: 1125773 http://dx.doi.org/ 10.1080/ 23311932.2015.1125773.

De Mesa-Stonestreet, N.J., Alavi, S., and Gwirtz, J. (2012). Extrusionenzyme liquefaction as a method for producing sorghum protein concentrates. J. Food Eng. 108, 365-375.

Deora, N.S., Deswal, A., and Mishra, H.N. (2015). Functionality of alternative protein in glutenfree product development. Food Sci Tech Int. (5): 364-79. Doi: 10.1177/1082013214538984. Abstract.

El-Khawas, K. M. and Hassaan, H. M. (2015). Control of food poisoning bacteria during manufacturing of acid cheese using some organic acids. Assiut Vet. Med. J. 61: 40-46. 
EL-Mahdi, L. D., Saad, S. A., Hassan, Z. M. R. and Awad, R. A. (2014). Starch and other stabilizers combinations asthickening agents in processed cheese sauces manufacture. J. Food and Dairy Sci., Mans Univ., 5 (11): 827 -840 .

El-Sayed, H. A., Tawfek, M. A. and Ali, Z. A.(2016). Making Kareish Cheese With High With Added Sesame Hulls. J. Food and Dairy Sci., Man Univ., Vol. 7 (2): 97 - 105.

El-Shimy, N. M. A. H. (2013). Effect of Chickpea Substitute in the Quality Characteristics of Biscuits and Cake. Bull High Inst Public Health. 43, 1: 58- 74

Fărcaş, A.C., Socaci,S.A., Tofană,M., Mureşan,C., Mudura, E., and Scrob, L.A.S. (2014). Nutritional properties and volatile profile of brewer's spent rain supplemented bread. Romanian Biotechnological Letters. 19, 5: 9705-9714.

Figuerola, F., Hurtado, M. L., Estévez, A. M., Chiffelle, I., and Asenjo, F. (2005). Fibre concentrates from apple pomace and citrus peel as potential fibre sources for food enrichment. Food Chem, 91, 395-401.

Gallagher, E., Kenny,S. and Arendt, E.K. (2005). Impact of dairy protein powders on biscuit quality. Eur Food Res Tech. 221:237-243.

Ghada, Z. A. A., Alia, M. H. Soha Al, S,. Magdy, N. A. and Mohamed, F. S. (2004). Chemical, Nutritional and Microbiological Evaluation of Some Egyptian Soft Cheeses. Egyptian J Hospital MedicineVol. 17, 44-57.

Gularte, M.A., GÛmez, M., and Rosell, C.M. (2012). Impact of legume flours on quality and in vitro digestibility of starch and protein from gluten-free cakes. Food Bioprocess Technology: An Int J. 5, 3142-3150.

Hefnawy, T. M. H., El-Shourbagy, G. A., Ramadan, M. F. (2012). Impact of adding chickpea (Cicer arietinum L.) flour to wheat flouron the rheological properties of toast bread. Int Food Res J. 19(2): 521-525.

Hegazy, N.M., Nasr, M.M., Fayed, A.E., Youssef, M.S. (2012). Economics scale for processing of white soft cheese in Egypt. Egypt J. Agric. Econ. 22, 1079-1094.

Hu, G.H., Yang, F., MA, Z. and Zhou, Q. (2007). Development of Research and application of rice bran dietary fiber. China Food Additives, 84 (5): 80-85

Hussein, A. M. S., Saleh, Z. A., Badawy, I. H. and El-Shobak. (2008). Rheological and sensory evaluation of some snacks modified to improve their nutritive and health value. Mans J of Agric Sci, 3, 1: 321 - 330.
Ihekoronye, A.I. and Ngoddy, P.O. (1985): Integrated food science and technology for the tropics. Macmillan. London, United Kingdom.

Izembaeva, A. K., B., Muldabekova, Z. H. I., Iztaev, A. and Zhienbaeva, S. T. (2013). The use of composite mixtures in the production of biscuits. Bulge. J. Agric. Sci., 19: 28-31.

Koubaier, H.B.H., Snoussi, A., Essaidi,I., Chabir, M. and Bouzouita, N. (2015). Cake quality evaluation made of wheat-lentil flour blends. / $\mathrm{J}$ of new sci, Agric and Biotech, JS-INAT. 17:, 937-942.

Krupa, H., Jana Atanu, H. and Patel, H. G. (2011). Synergy of dairy with non-dairy Ingredients or product: A review. Afr. J. Food Sci. 5, 16: 817-832.

Lucey, J.A. (2008). Some perspectives on the use of cheese as a food ingredient - A Review. Dairy Sci. Technol., 88: 573-594.

Man, S., Păucean,A. Muste,S. and Pop, A. (2015). Effect of the Chickpea (Cicer arietinum L.) Flour Addition on Physicochemical Properties of Wheat Bread. Bulletin UASVM Food Sci and Tech. 72(1): 41-49.

MAN, S.M., Paucean, A. and Muste, S. (2014). Preparation and quality evaluation of glutenfree biscuits. Bulletin UASVM Food. Sci and Tech, 71(1): 38-44.

Mariotti, M., Lucisano, M., Pagani, M. A., and Ng, P. K. W. (2009). The role of corn starch, amaranth flour, pea isolate, and Psyllium flour on the rheological properties and the ultrastructure of gluten-free doughs. Food Res Int, 42: 963-975.

Matos, M.E. and Rosell, C.M. (2012). Relationship between instrumental parameters and sensory characteristics in gluten-free breads. Eur. Food Res. Tech. 235, 107-117.

Matos, M.E., Sanz,T. and Rosell, C.R. (2014). Establishing the function of proteins on the rheological and quality properties of rice based gluten free muffins. Food Hydrocolloids 35: 150-158.

Miñarro, B., Albanell, E., Aguilar, N., Guamis, B. and Capellas, M. (2012). Effect of Legume Flours on Baking Characteristics of GlutenFree Bread. J of Cereal Sci, 56, 476-481. http://dx.doi.org/ 10.1016/j.jcs.2012.04.012.

Mishra, A. Devi, M. and Jha, P. (2015). Development of gluten free biscuits utilizing fruits and starchy vegetable powders. J Food Sci. Tech. 52(7): 4423-4431. DOI 10.1007/s13197-014-1521-5.

Mishra, N. and Chandra, R. (2012). Development of functional biscuit from soy flour \& rice bran. Int. J. of Agric. and Food Sci., 2(1): 14-20. 
Osella,, C., Torre,M. and Sánchez, H. (2014) Safe Foods for Celiac People. Food and Nutr Sci, 5 , 787-800. http://dx.doi.org/10.4236/fns.2014.59089.

Osorio-Díaz, P., Agama-Acevedo, E., MendozaVinalay, M., Tovar, J. and Bello-Pérez, L. A. (2008). Pasta added with chickpea flour: chemical composition, in vitro starch digestibility and predicted glycemic index. Cienc. Tech. Aliment. 6(1): 6-12.

Oyarekua, M.A. and Adeyeye, E.I. (2009) Comparative Evaluation of the Nutritional Quality, Functional Properties and Amino Acid Profile of Co-Fermented Maize/Cowpea and Sorghum/Cowpea Ogi as Infant Complementary Food. Asian J of Clinl Nut, 1, 31-39.

Patil, S.S., Brennan, M.A,. Mason, S.L and. Brennan, C.S. (2016). The Effects of Fortification of Legumes and Extrusion on the Protein Digestibility of Wheat Based Snack. Foods 2016, 5, 26; doi:10.3390/foods5020026.

Rababah, T. M., Al-Mahasneh, M.A. and Ereifej, K.I. (2006). Effect of chickpea, broad bean, or isolated soy protein (ISP) additions on the physicochemical and sensory properties of biscuits. J. Food Sci., 71: 438-442.

Romeih, E.A., Michaelidou, A., Biliaderis, C.G., and Zerfiridis, G.K. (2002). Low-fat white brined cheese made from bovine milk and two commercial fat mimetics, physical and sensory attributes, Int Dairy J, 12, 525-540. doi: 10.1016/S0958-6946(02)00043-2.

Saleh, A.M., Salama, A.E.D., Bedeir, S.H. and AbdElazim, E.I. (2012). Effect of partial substitution of wheat flour with either defatted soybean or chickpea flours at different ratios on rheological and physical properties of dough, and quality characteristics of biscuits J. Apple. Sci. Res., 8(12): 5806-5817.

Sulieman, A.E.M., Sinada, E.A., and Ali, A.O. (2013). Quality characteristics of Wheat Bread Supplemented with Chickpea (Cicer arietinum) Flour. Int. J. of Food Sci and Nutr Eng. 3(5): 85-90.
Surojanametakul, V., P. Tungtrakul and Varanyanond, W. (2006). Factors affecting water soluble polysaccharide content and pasting properties of Thai glutinous rice. Kasetsart J. (Nat. Sci). 40: 117-124.

Thongram, S., Tanwar,B., Chauhan,A. and Kumar, V. (2016) Physicochemical and organoleptic properties of cookies incorporated with legume flours .Cogent Food \& Agric 2: 1172389

http://dx.doi.org/10.1080/23311932.2016.117 2389

Tsatsaragkou, K., Yiannopoulos, S., Kontogiorgi, A., Poulli, E., Krokida, M. and Mandala,I. (2012). Mathematical Approach of Structural and Textural Properties of Gluten Free Bread Enriched with Carob Flour. J of Cereal Sci, 56 , 603-609. http://dx.doi.org/10.1016/j.jcs.2012.07.007

Turabi, E.; Sumnu, G. and Sahin, S. (2008). Rheological properties and quality of rice cakes formulated with different gums and an emulsifier blend. Food Hydrocolloids., 22: 305-312.

Wani, S.A. and Kumar, P. (2014) .Comparative study of chickpea and green pea flour based on chemical composition, functional and pasting properties. J. of Food Res and Tech. 2, 3:124-129.

Wood, J.A. and Grusak, M.A. (2007). Nutritional Value of Chickpea. In: Yadav, S.S.,Redden, B., Chen, W., Sharma, B. (Eds.), Chickpea Breeding and Management. CAB International, Wallingford, UK, 101-142.

Yamsaengsung, R., Berghofer, E. and Schoenlechner, R. (2012). Physical properties and sensory acceptability of cookies made from chickpea addition to white wheat or whole wheat flour compared to gluten-free amaranth or buckwheat flour. Inter. J of Food Sci \& Tech, 47: 2221-2227.

Zhang,T., Jiang, B., Wang, Z. (2007). Gelation properties of chickpea protein isolate. Food Hydrocolloids, 21: 280-286. 


\title{
المالهص المري
}

\section{تأثير تدعيم البسكوبت خال الجلوتين بقيق الحهص والجبن الفرب عل التركيب

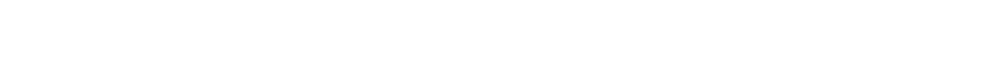

\author{
إيملن عبد الحميد ألحمد عبد ربه المبار \\ قسم الاقتصاد المنزلي - كلية التربية النوعية - جلمعة أسوان
}

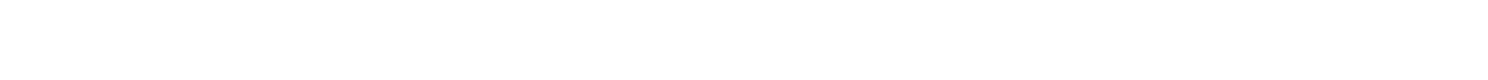

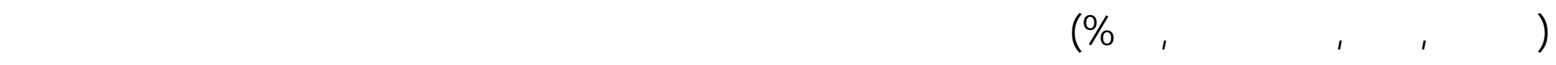

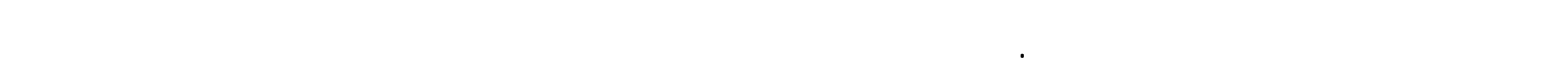

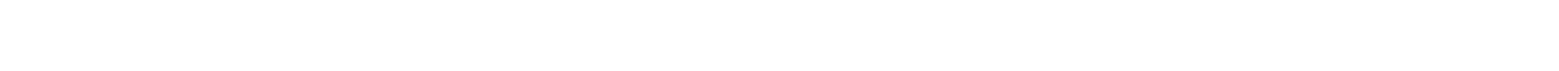

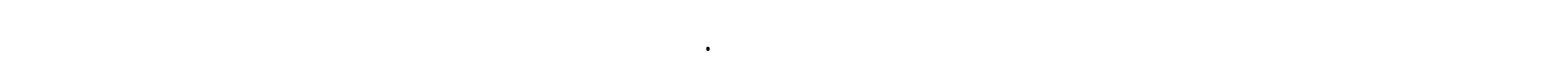

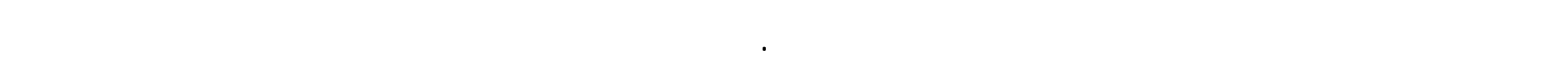

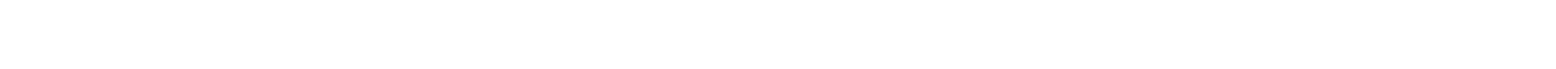

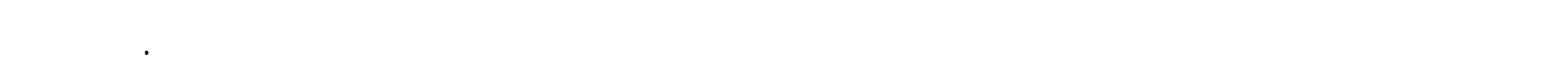

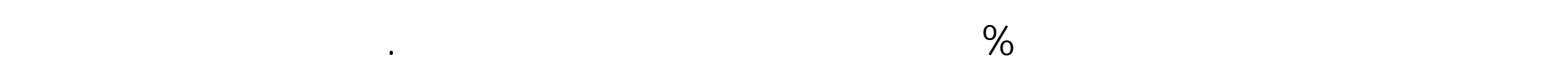

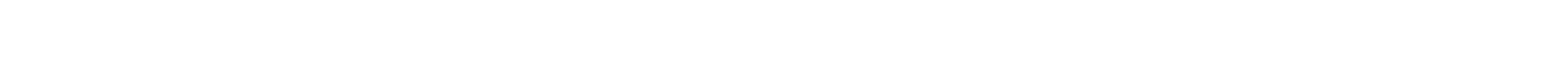

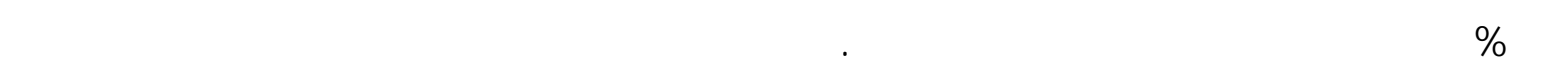

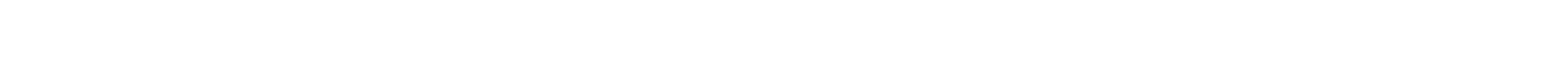
القربيش بنسب متوسطة. 